\title{
African Parents as Partners in School Governance in South Africa?
}

\author{
M P Mavuso \\ University of Fort Hare, School of Further and Continuing Education \\ Alice, 5600 \\ pmavuso@ufh.ac.za \\ N. Duku \\ University of Fort Hare, School of General and Continuing Education, \\ East London, 5200 \\ nduku@ufh.ac.za
}

Doi:10.5901/mjss.2014.v5n16p427

\begin{abstract}
Partnership in education is a global phenomenon, which is relatively new in the South African context. This is especially so in African communities, which pre-1994 did not have legitimate representation in education issues. This paper problematizes the phenomenon of school- parent partnership. The paper acknowledges that parental representation in the selected schools is in line with the prescriptions of South African Schools Act (SASA) 84 of 1996. This inclusion only refers to their numerical representation. When it comes to participation, however the parents seem to have positioned themselves as outsiders, as have educators. As a result, parents mostly rely on and rubber stamp whatever the educators have already decided. This study used the qualitative research approach through structured and semi structured interviews and documentary analysis to investigate how the partnership between parent SGB members and educators unfolds in school governance. From the findings it emerged that parent SGB members were mere pseudo partners in matters of policy development and implementation in the selected schools. As the government has enacted some progressive pieces of legislation such as SASA, this paper is calling for communities, especially Black African one to regroup and reclaim their place in education as they did, when they reclaimed their political freedom from the minority white regime pre- 1994.
\end{abstract}

Keyword: Community involvement, Decentralisation, Democratisation, Parents, Participation, Partnership, Representation, School governance, School Governing Body, Pseudo- partners

\section{Introduction}

For some time now, partnership in education has been regarded as great phenomenon internationally. It is seen as a relationship between schools, families, and communities and as a means for promoting student achievement (Davies \& Johnson, 1996; Epstein \& Sanders, 1998; Henderson, 1987; Swap, 1993). This implies, therefore, that partnership in education is a means by which the partners are in constant interaction with each other in an endeavour to improve academic achievement of students (Epstein, 1995). Hands (2005) further argues that the advantage to a community of involvement in their children's schooling is two-fold: enhancing students' learning opportunities and easing the transition from high school. This two-fold advantage creates recognition of the valuable role that partnerships can in schooling.

In South Africa, partnership in education came into existence when the DoE decentralised the education system through the promulgation of South African Schools Act no 84 of 1996. Decentralisation was a strategy used by the state to share its power with other stakeholders in education, particularly those who are closer to the school, in order to bring about improved control of the schools (van Wyk, 2004). The debate around the problems that seem to persist in education, especially at the primary level, resulted in an approach that was intended to bring about reforms (democratisation) in the schooling system. These reforms were introduced within the parameters of decentralisation (Maclure, 2004 \& Mavuso, 2009). It was hoped that the decentralisation of education would bring about a greater responsiveness to the needs of the particular local people in each school community. A high level of participation was also a focal point in the decentralisation of education (Ibid, 2004). Parents were made to participate in school governance by electing the SGBs. The SGBs were expected to deal with all the issues of school governance. These include, among other issues, developing the mission statement of the school; adopting a code of conduct for learners and determining the admission and language policy of the school within the framework of the constitution of the Republic of South Africa (van 
Wyk, 2004).

In a newsletter published by USAID's EQUIPI (2005), educational decentralisation is noted as the devolution of service delivery roles from national to lower levels of governments and the delegation of service delivery decisions and functions to the level of the school. "One of the purposes of decentralising education services is to widen the participation of non-education professionals at local community level, in the running and management of schools" (Dunne, Akyeampong \& Humphreys, 2007: 16). The decentralization of school governance was based on the assumption that decentralised systems are leaner and therefore better at responding to local needs. It was hoped that it would bring about enhanced service delivery in developing countries (Ibid, 2007). "Within the local community context, shared educational concerns, such as a persistent dropout rate, high pupil absenteeism, and utilisation of school fees are expected to galvanize community and local government action" (Chapman, 2000 in Dunne, Akyeampong \& Humphreys, 2007: 10 ). This study therefore seeks to investigate how the partnership between parents and educators works. In South Africa SASA was promulgated to achieve partnership in school governance in a decentralized context.

School governance pre-1994 used to be characterized by authoritarian and exclusive practices (Duku, 2006 and Mavuso, 2009). Schools were governed by the school boards or school committees which were not democratically elected (Mbantsane, 2006), and these committees were expected to serve the interests of the Apartheid government. This meant that committees did not serve the interests of the communities they represented. They were just agencies of the state carrying out the will of the legislative assembly. However, some writers such as Soudien (2003) and Duku (2006), criticize SASA for being too much aligned to the middle class in quality, and for couching parental participation in middle class terms, without much regard for underprivileged societies. "SASA, for instance, makes implicit assumptions about parents; for example: that they can all afford personal time to spend on school activities which are not related to any form of remuneration, and that they have the resources to make choices about their children education" (Soudien, 2003; Sayed \& Soudien, 2005 in Duku, 2006: 140). As a result, in some communities, particularly in rural areas, parents seem to rely on educators in matters of school governance (Duku, 2006; Mncube, 2009 and Mavuso, 2011). Consequently, school governance does not follow the direction anticipated by SASA, especially in rural areas.

Despite the criticisms raised here, there seems to be an overwhelming agreement on the importance of parental participation in school governance (see Sayed, 2002; Suzuki, 2002; Duku, 2006; Mbantsane,2006; Lusaseni,1998; Maclure,1994; Mathonsi, 2000; Heystek,2004; Lewis \& Naidoo,2005 and Mncube, 2009). As other social dynamics seem to frustrate the achievement of the SASA philosophy, the concern turns to the consideration of the type of partnership that occurs between teachers and parents. Hence, this paper aims to examine the kind of partnership between parent SGB members and teachers.

The research question this paper aims to address is:

How do partnerships between parents and educators operate in school governance?

\section{Theoretical Framework}

\subsection{Epstein's theory of overlapping spheres of influence}

The study was informed by Epstein's theory of overlapping spheres of influence. Epstein (2010) argues that schoolcommunity partnerships refer to the connections and interactions between schools and community individuals and organizations that are created to enhance students' social, emotional, and intellectual and academic development (Sanders, 2006). Epstein's theory of overlapping spheres of influence emphasizes that goals for student academic success are best achieved through the cooperation, and support of schools, families, and communities and the kind interaction these must have in pursuit of such goals (Epstein, 2011). Hence, there has been a growing interest in schoolcommunity partnerships in education worldwide (Epstein, 2010a; Faulconer, 2010; Gestwicki, 2013; Sanders, 2006, 2008; Sheldon, 2007). This study focused on how the partnership between parents and educators plays itself out in school governance.

It has been suggested that, in many communities, partnerships between schools and other community organizations, parents and agencies are helping to create support that enables children and youth to learn and to succeed. (Center for the Study of Social Policy, 1998). These partnerships bring together diverse individuals and create a forum in which diverse ideas can be concretised into solid, effective educational programmes.

Through open dialogue between individuals, during which conversation, discussion and deep listening takes place, participants foster the "social creativity" (Jenlink \& Banathy, 2005, p. 7) that is necessary for the establishment of novel ways of interacting with others, such as partnership development. In order to foster the communication and cooperation essential for establishing partnerships, Darling-Hammond \& Lieberman, 1993; Epstein, 2001; Sanders, 2001 note that 
identifying goals, defining the focus of the partnerships, and selecting potential community partners are crucial steps for building successful collaborations in the implementation of the partnership. In the case of school governance in South Africa, parents were made partners at school level in the education system through enactment of SASA.

While Epstein views parental involvement in activities as the primary focus of the interaction between schools and their external environments, Sanders (2001), provides further categorization of activities established between individuals in the schools and members of their communities. These are: student support, family support, school improvement, or community development. This categorization may be broadened. Wohlstetter et al (2003) emphasise activities such as curriculum, facilities, financial assistance, business and management expertise, liaisons with community, assistance with administrative procedures, and enhancing schools' legitimacy as those that parents and educators should work on in partnership. Sanders, 2001 argues that, once collaborative activities are established, they are monitored and evaluated, and success stories from the partnerships are shared. Hence, this study sought to explore how parents and educators work in partnership in the business of education, particularly school governance.

\section{Research Methodology}

This study adopted a qualitative research methodology within the parameters of the interpretive paradigm. Qualitative research is an approach in which researchers are concerned with understanding the meaning which people attach to their experiences or phenomena within their societies (Ritchie \& Lewis, 2003). The researchers used the qualitative research because the focus of this study was on investigating the partnership between parents and educators in school governance and the meaning the parents attach to their participation in school governance. The qualitative approach which was used in this study emphasizes the knowledge and practices that are studied at the local level (Flick, 2006). The interpretive paradigm is about understanding the everyday experiences of people in a specific area or historic setting. (de Vos, 2002). It is about epistemology that advocates that it is necessary for the researcher to understand the human's roles as social actors and the meaning the humans give these roles (Ibid, 2006). This research falls within this paradigm, in that, it investigates how parents participate in school governance.

Two rural primary schools were selected for this study. These schools were sampled because they were both primary schools in black, rural areas. The sample comprised of 36 respondents. Of the 36 respondents, 2 were school principals 4 SGB educators, 2 SGB chairpersons, 2 SGB secretaries and 2 SGB treasurers. There were also 2 SGB nonteaching staff members and the rest were non SGB parents.

The researchers used multiple data collection methods namely: structured interviews, semi- structured interviews, document analysis and non-participatory observations. The interview is any formal person - to - person interaction between two or more people with a specific purpose or objective in mind on a specified date and time (Kumar, 2005). In using the structured interviews, the researchers probed the respondents' reasoning because they wanted them to respond to a standard set of questions. A structured interview is a technique that is easy to administer because it permits the researcher to have the well defined role of sitting with the questionnaire in his/her lap (Plummer, 2001). In this type of research method, the researcher gains the relative security of knowing both what to ask and what is likely to be heard in the reply (Plummer, 2001). This means, therefore, that structured interviews use pre-established questions that are asked in a predetermined order (O'Leary, 2004). Semi-structured interviews are neither fixed nor fully free and yet they are a flexible research technique or method (O'Leary, 2004). This means that the order of the questions as advised by (Robison, 2002) is changed depending on the situation the researcher encounters. With the use of semi-structured interviews in this study, the researchers wanted the respondents to expatiate as much as they could on certain points. This also helped the researchers probe respondents' reasoning and to ask clarity seeking questions. The interviews were conducted in the respondents' homes and they were tape recorded verbatim. A documentary analysis was done with the aim of understanding the participants actions and the meaning they attach to their actions. SGB minute books and parent meeting minute books were analysed. Document analysis is the situation in which the researcher reads and analyses important documents such as minutes of the meetings, newspaper articles and historical archives and previously gathered census data. It is the process which is followed, with the aim of understanding the participants' actions and the meaning they attach to their actions or events (O'Leary, 2004, Mouton, 2005; Plummer, 2001, O'Leary, 2004).

\section{Presentation and Discussion of Findings}

\subsection{Parent-Educator partnership in school governance}

This section discusses the findings that emerged from the data and relates them to the literature that has been reviewed 
above. The concepts that were discussed earlier serve as lenses through which the partnership between parents and educators in SGBs is viewed. In this section the researchers discuss the findings from both schools.

Regarding the calling of the meetings it emerged from the data that the principal is the person who calls school meetings. One participant noted that, "The principal is the head of the school therefore it is his role to call the SGB meetings". This may be an indication that the principal is the person who is knowledgeable in matters of school governance as he represents the DoE. Some respondents even referred to him as the Chief Executive Officer (CEO) of the school which meant that he was a superior in matters of school governance. Though Epstein (2005) defines partnership as constant interaction and collaboration between parents and educators, parents seemed to regard themselves as outsiders in matters of school governance. In most cases, the principal was expected to inform the parents of the developments in the DoE. Writers, such as Farrel (2001), view the partnership between the principal and the SGB chairperson as vital in school governance. The principal represents the DoE while the SGB chairperson represents the interests of the community (Ibid, 2001). However, the partnership seemed unequal, as it was the principal, in most cases, who initiated meetings with the SGB chairperson.

The issue of collaboration raised by Heystek (2004) seemed to prevail between the SGB chairperson and the principal, in that, the principal appeared to have one-on-one sessions with the SGB chairperson. One SGB chairperson commented that,

Besides chairing the SGB and parents meetings, I monitor the activities of the SGB and I am the first person to be informed by the principal of any development in the school. Together with the principal we decide on the date that we should call SGB meeting.

After the session between the principal and the SGB chairperson, an SGB meeting would be called and it was reported to be the role of the principal to call these meetings. This was an indication that parent SGB members' participation in school governance was limited, as they regarded calling SGB meetings the principal's prerogative. One school principal had this to say about the SBG chairperson:

He is the person who assists with the school governance, who comes to school regularly. He only assists in matters of school governance, not in matters of school management. He assists the principal in seeing to it that the school runs effectively and efficiently.

The majority of the respondents, as indicated above, noted that it was the role of the chairperson to chair SGB parent meetings. However, there were a few respondents who indicated that the chairing of the school meetings was done by the principal and the SGB chairperson. The fact that the principals sometimes chaired the SGB meetings may be an indication that they usurp the role of the SGB chairperson in school governance. This usurping of the SGB chairperson's role by the principal is what Heystek (2004) refers to as 'power plays', which may be conscious or unconscious. The power plays happen when the principal dominates the SGB or the SGB chairperson dominates the principal (Ibid, 2004). This may also be an indication that parent SGB members are unsure of their function in school governance and perhaps regard themselves as outsiders in the business of school governance.

Regarding parent SGB members' participation in the formulation of policies and their implementation, the majority $(80 \%)$ of respondents reported that it was the role of the SGB to formulate and ensure the implementation of school policies. Another $80 \%$ reported that parents do formulate school policies in their general meetings. This was an indication that parent SGB members were not sure at which level of school governance their participation in matters of policy formulation was required. However, this was an indication that parental participation has been enhanced, since parents were reported to make decisions on school policy formulation, and perhaps, in principle, they realized that they were expected to participate in the policy formulating business. This was therefore consistent with what Lewis \& Naidoo (2005) refer to as involving stakeholders in making decisions by consensus. However, the SGB must formulate policies within the prescribed parameters of the DoE. This means that the SGB cannot formulate a policy that is contrary to the broader policy of the DoE. For instance, the SGB is required to have policy on admissions and yet the DoE has a policy on admissions on matters pertaining to age requirements and timeframes for admissions.

When asked about his role, one SGB chairperson said, "I ensure that rules and policies of the school are implemented. For example when a learner misbehaves I see to it that proper disciplinary measures are followed". One school principal reported the process in this way:

Educators sit in a meeting and come up with proposals on certain issues. These proposals are taken to the SGB by those educators in the SGB. The SGB discusses and drafts a policy to be presented to the parents meeting. The 
parents are the last persons to have a say and it is endorsed as a policy of the school by the parents.

The fact that the SGBs reported regularly to the parents on progress in the school, and require parents to have a say and to make some decisions on the education of their learners was a reflection of what Maclure (1994) calls decentralisation of education. The majority of respondents view the role of the SGB as that of formulating school policies and this is consistent with what Mathonsi (2006) views as a delegation of power to the local people. However, their participation and decision making is limited because they operate within the readymade policies of the DoE. This is what Arnstein (1967) refers to as 'placation'. Placation is just a higher or advanced level tokenism because the ground rules allow the have-nots to advise, but retain for the power- holders the continued right to decide. It allows citizens to advise or plan ad infinitum but retains for power-holders the right to judge the legitimacy or feasibility of the advice (Ibid,1967). However, there were no indications that the parents, in their meetings, initiated issues which become part of school policy. The parents meetings were dominated by reports by the SGB and the parents participation was limited to asking for clarity on certain issues. Educators seemed to direct these meetings. They answered questions raised by the parents and in most cases provided solutions to problems. For instance, during the SGB meeting in school A the researcher observed that one parent SGB member was given a platform to report on the issue of educational tours. She reported on that particular issue but she sought additions from the educators.

SASA requires that SGBs establish SGB committees whose members are mainly parents. The aim of establishing these SGB sub committees is to enable the SGB to execute its roles effectively. This means that, according to Arnstein (1967) the system of school governance allows for 'citizen control' where parents are expected to be in the majority in SGBs and their sub committees. Lenin (2009) further noted that a situation, where partners are actively involved in a business or business relationship is an active partnership. However most of the SGB sub committees were reported to be dysfunctional and their tasks were performed by the SGBs in which the educators play a dominant role. This means therefore that, though the involvement of parents in decision making was an indication of the democratization of school governance, what Mathonsi (2001) referred to as 'delegation of powers' within the SGB was still lacking. That most of the SGB subcommittees were dysfunctional, makes the SGBs look like a nerve centre that does not have enough branches to support it in executing its duties. No other persons were reported as serving in the SGB subcommittees. This was an indication that community involvement was limited to decision making at the level of parent meetings. On certain school governance matters that required some expertise, the community was not involved. This was in violation of the SASA (1996) prescription that the SGB appoint, on the basis of expertise, other persons who are not members of the SGB, to serve in these committees.

Regarding the management of school finances it emerged that this was largely dependent on the educators. In this regard the issue of mentoring as argued by Crawford \& Earley (2004) and Mathonsi (2001) appears crucial as it seemed educators and the principal assisted the parent SGB members in financial management. It was reported that, on many occasions, the principal gave direction on matters of school finance. This may be an indication that parent SGB members needed a person with expertise to guide them on SGB financial matters.

There were no sessions reported that dealt with the book keeping of school finances by the finance committee. The processes of budgeting were apparently not handled by the SGB finance subcommittee. It also emerged from the report that the finance committee meetings are not held regularly, that is, there was no schedule of meetings by the finance committee. There were no reports on the procedures followed when the school purchased goods, except for educators having to secure quotations from different shops. The processes that are followed during cheque requisition were also not reported. This means that parent SGB members need support to be able to perform their roles effectively.

The data also indicated that the SGB chairperson and other SGB members sometimes visited school to check that teaching was taking place. This may be an indication that the parent SGB members did not understand their roles in ensuring a culture of teaching and learning. SASA (1996) prescribes that the principal of a school see to that all the education programmes and curriculum activities are implemented and that there is academic improvement in a school. Their visits therefore meant that some parent SGB members did not differentiate between the roles of the SGB and those of the SMT.

It emerged from the data that the SGB and non SGB members had similar conceptions of the factors that affect school governance. These included commitment, punctuality, dedication, trust and respect. Amongst the complaints that the respondents reported was the lack of support from the Department of Education. Crawford \& Earley (2004) indicated that the lack of mentoring of SGBs in executing their roles brings about factors that are detrimental to school governance. 


\section{Conclusion and Recommendations}

From the above presentation one could deduce that Black African parents, educators and principals have different conceptions and assumptions about the roles of parents in school governance. The data suggested that parents were involved in decision making as both SGB members and as parents. However, educators seemed to be playing a leading role in matters pertaining to school finances, formulation of policies and ensuring the culture of teaching and learning. Parents were regarded as crucial stakeholders in their children's education. However, they seemed to regard themselves as outsiders on certain issues of school governance and in some cases were unable to distinguish between the roles of the SMT and those of the SGB concerning the culture of teaching and learning. Females were in the majority in the SGBs, although they were reluctant to assume leadership positions as they saw such positions as meant for males. It also became clear that SGB subcommittees which parents were members of did not support the SGB. Furthermore, the majority of parents regarded school governance as an issue better understood by the educators.

This study recommends therefore that African Black parents reclaim their role in matters of education; particularly school governance, which is a support tool for learners' academic achievement. Parents and the youth pre-1994 played a pivotal role in bring about transformation in education. The period from 1976 to the late 1980s was characterized by student uprisings which were aimed at bringing changes to the education system., With the advent of democracy, this resulted in the promulgation of progressive pieces of legislations in education such as SASA. Many of the then youth are parents today. It is for this reason that this article calls for Black African parents to reclaim their hegemony in the education system. By reclaiming their position and playing an active role in the education of the African child parents would be engendering Nelson Mandela's call for educating the African child for the total liberation of this country. In South Africa rural schools are still regarded as inferior in matters of education partnership, particularly school governance. This paper also recommends that the DoE, with the aim of redressing the imbalances of the past, embark on SGB capacitating programmes that are sensitive to the situation in the rural areas.

\section{References}

Adams F \& Waghid $Y$ 2005. In defence of deliberative democracy: Challenging less democratic school governing body practices, South African Journal of Education, 25(1): 25-33.

Arnstein SR 1967. A ladder of citizen participation, JAIP: 216-224.

Brown B \& Duku N 2007. Parents' participation in school governance in South Africa: social identies and policy implications, Journal of Educational Studies, 6 (2):139-178.

Brown B \& Duku N. 2008. Negotiated Idendities: Dynamicis in parent participation in school governance in rural Eastern Cape schools and Implication for school leadership, South African Journal of Education, 28(3):431-450.

Bühler, U 2001. Participation 'with Justice and Dignity': Beyond 'the New Tyranny'. United Kingdom: University of Bradford.

Burde, D 2004. Weak State, Strong Community? Promoting Community Participation in Post-Conflict Countries, Current Issues in Comparative Education, 6(2): 73-87.

Bush, T \& Heystek, J 2003. School Governance in the New South Africa, Compare, 33(2): 127-138.

Carnaby, P (2009) National libraries in the digital age, leadership and Collaboration, Wellington: IFLA.

Chikoko, V 2007. Negotiating roles and responsibilities in the context of decentralized school governance:A case study of one cluster of schools in Zimbabwe. International Studies in Educational Administration, 35(1): 22 - 40.

Cleaver, F 1999. 'Paradoxes of Participation: Questioning Participatory Approaches to Development', Journal of International Development, 11: 597-612.

Cleaver, F 2001. 'Institutions, Agency and The Limitations of Participatory Approaches to Development'. In B Cooke and U Kothari, (eds). Participation: The New Tyranny?, London: Zed Books.

Center for the Study of Social Policy 1998. Creating A Community Agenda: How Governance Partnerships Can Improve Results for Children, Youth, and Families. Washington.

Davies, D \& Johnson, V R 1996. Crossing boundaries: Family, community, and school partnerships. International Journal of Educational Research, 25(1):1-105.

De Vos, A, Srydom, H, Fouche, CB \& Delport, CSL 2002. Research at Grass Roots, Pretoria: Van Schailk Publishers.

Duku, N 2006. The exploration of parents' negotiations of their identities in school governance participation in six selected villages. PhD thesis. Cape Town: University of Cape Town.

Dunne, M Akyeampong, K \& Humphreys, S 2007. School Processes, Local Governance and Community Participation: Understanding Access, Create, Consortium for research on Transitions and equity, 6: 1-90.

Epstein, J L 1995. School/family/community partnerships: Caring for the children we share. Phi Delta Kappan, 76(9): 701-712.

Epstein, J L \& Sanders, MG 1998. What we learn from international studies of schoolfamily-community partnerships. Childhood Education, 74(6): 392-394.

Epstein, JL 2001. School, family, and community partnerships: Preparing educators and improving schools. Boulder, CO: Westview 
Press.

Epstein, J L 2010a. Caring connections. Phi Delta Kappan, 92(3), 65

Epstein, J. L. 2010b. School/family/community partnerships: Caring for the children we share. Phi Delta Kappan, 92(3): 81-96.

Epstein, JL 2011. School, family, and community partnerships: Preparing educators and improving schools. Boulder, CO: Westview Press.

Farrel, M 2001. Key issues for secondary schools, London, Routledge Falmer.

Flick, U. (2006). An Introduction to Qualitative Research, London, SAGE Publishers.

Hands, C 2005. It's who you know and what you know: The process of creating partnerships between schools and communities. School Community Journal, 15(2): 64-84.

Henderson, A (1987. Evidence continues to grow: Parental involvement improves student achievement. Columbia, MO: National Committee for Citizens in Education.

Heystek, J 2004. School Governing Bodies- the principal's burden or light of his/her Life, South African Journal of Education, 24(4): 308312.

Jenlink, PM \& Banathy, BH 2005. Dialogue. In B. H. Banathy \& P. M. Jenlink (eds) Dialogue as a means of collective communication (pp. 3-14). New York: Kluwer Academic Plenum Publishers.

Kabacoff, R.I. \& Stoffy, R.W. (2001). Age Difference in Organizational Leadership, A paper presented at the $16^{\text {th }}$ Annual Conference of the Society For industrial and Organizational Psychology, San Diego: California.

Karlson, J 2002. The Role of Democratic Governing Bodies in South African Schools, Comparative Education, 38(3): 327-336.

Kumar, R 2005. Research Methodology. London: SAGE Publishers.

Kelly, MJM 1997. Gender Differences and Leadership, A research report submitted in partial fulfillment of the curriculum requirement, Air War College: Air University.

Kezembe, MB 2005. Retracing Footsteps of the Literati: Towards an understanding Of literacy development through stories of Malawian Teacher Educator, PhD thesis. Virginia: State University.

Lenin, S 2009. Partnership and types of partnership, Indiastudychannel.com.

Lewis, SG \& Naidoo, J 2005. School Governance and the Pursuit of Democratic Participation, International Journal of educational Development, 26(4): 415-427.

Ludovina, F 2002. Fostering Home- School Partnership, Preschool Coordination Project, San Diego.

Lusaseni, PH 1998. An investigation of how members of a school governing body perceive and experience their roles, A case study, Rhodes University.

Maclure, R 1994. Misplaced assumptions of decentralization and participation in In rural communities: primary school reform in Burkina Faso, Comparative Education, 30(3), 239-254.

Mathonsi, V 2000. Transforming governance and management of education-The case for South Africa, Gallagher Estate.

Mavuso, MP 2009. An exploration of the roles of the parent SGB members in the SGB: A case study of two selected rural primary schools in the King Williams Town District. Med thesis. Alice: University of Fort Hare.

Mbantsane, PN 2006. The Financial accountability of School Governing Bodies: unpublished Masters' Degree Thesis, University of Pretoria, Gauteng, South Africa.

Mbasa,T \& Themane, J 2002. Stakeholder Participation in School Governance in South Africa, Perspectives in Education, Vol 20(3):111116.

Mncube, V 2009. Perceptions of the principal's role in the democratic governance in in South Africa, Journal of Educational Administration and History, 41(1):29-43.

Mestry, R \& Grobler, B 2007. Collaboration and communication as effective strategies for parental involvement in public schools, Educational Research and Review, 2(7):176-185.

Motimele, M 2005. School Governing Bodies, Education, Rights Projects, Johannesburg: Wits University.

Mouton, J 2005. The Practice of Social Research. South Africa: Oxford.

O'Leary, Z 2004. The Essential Guide to Doing Research. London: SAGE.

Plummer, K 2001. Documents of life. New Dehli: SAGE.

Ritchie, J \& Lewis J 2003. Qualitative Research Practice. London: SAGE.

Robson, C 2002. Real World Research. UK: Blackwell Publishers.

Sanders, MG 2001. The role of "community" in comprehensive school, family, and community programs. The Elementary School Journal, 102(1):19-34.

Sayed, Y 2002. Democratising Education in a Decentralized System: South Africa policy and practice, Compare, 32(1):35-46.

Sidorenko, A 2006. Empowerment \& Participation in Policy Action on Ageing, International Design for All Conference, Rovaniemi, Finland - Full papers Keynotes.

Soudien, C 2003. Constiting and a class' :An analysis of the process of 'integration'in South African Schools, Changing Class.

Suzuki, I 2002. Parental participation and accountability in Primary schools In Uganda, Compare, 32(2): 243-259.

Swap, SM 1993. Developing home-school partnerships: From concepts to practice. New York: Teachers College Press.

USAID, 2005. Educational Quality in Developing World, EQ Review, 3 (4):1-4.

USAID, 2006. Peaks Regional Conference on School Governance in Central Asia, Academy of Educational development.

Van Wyk, W. 2004. School Governing Bodies: the experiences of South African Educators, South African Journal of Education, 24(1): 49-54. 
Wohlstetter, P Malloy, CL Smith, J.\& Hentschke, G 2003. Cross-sectorial alliances in education: A new approach to enhancing school capacity (Working paper). Los Angeles: University of Southern California, Rossier School of Education, Center on Educational Governance.

Xaba, MI 2004. Governors or watchdogs? The role of educators in the schooling bodies, South African Journal of Education, 24(4): 313316. 